Indonesian Journal of Biotechnology, June, 2013

Vol. 18, No. 1, pp.58-63

\title{
Chemosystematic of Enterobacteriaceae Familia Obtained from Blood Cultures Based on Total Protein Profiles
}

\author{
Sri Darmawati ${ }^{*}$, Langkah Sembiring ${ }^{2}$, Widya Asmara ${ }^{3}$, Wayan T. Artama ${ }^{4}$, \\ and Syaiful Anwar \\ ${ }^{1}$ Laboratory of Microbiology, Faculty of Nursing and Health, Universitas Muhammadiyah Semarang, \\ Semarang, Indonesia \\ ${ }^{2}$ Laboratory of Microbiology, Faculty of Biology, Universitas Gadjah Mada, Yogyakarta, Indonesia \\ ${ }^{3}$ Department of Microbiology, Faculty of Veterinary Medicine, Universitas Gadjah Mada, Yogyakarta, \\ Indonesia \\ ${ }^{4}$ Department of Biochemistry, Faculty of Veterinary Medicine, Universitas Gadjah Mada, Yogyakarta, \\ Indonesia \\ ${ }^{5}$ Faculty of Animal Husbandry, Universitas Diponegoro, Semarang, Indonesia
}

\begin{abstract}
The purpose of this study was to determine the chemosystematic of 14 strains of bacteria in blood cultures from Semarang using 1 reference strain S. typhi NCTC 786, based on the total protein profiles with the similarity relationship analysis based on Simple Matching Coefficient $\left(\mathrm{S}_{\mathrm{SM}}\right)$ analysis and algorithm method of unweighted pair group with averages (UPGMA) presented in a dendrogram. The results showed that the chemosystematic based on the total protein profiles using SDS-PAGE method can classify the member of bacterial strains of each species. The Clusters respectively consist of 4 strains of $S$. typhi (similarity: 89.7\%), 2 strains of Ser. marcescens (similarity: 89.7\%), two strains of E. coli, and one strain of Salmonella ssp, S. typhi NCTC 786 (similarity: 100\%). Those three incorporated clusters had the similarity value of $75.3 \%$. Those four strains of Ent. cloacae composed in one cluster (similarity: 100\%) are incorporated in a cluster consisting of one strain of Kleb. pneumoniae (similarity: 92.9\%). Both clusters were incorporated in a cluster consisting of S. typhi NCTC 786 (similarity: 67.9\%).
\end{abstract}

Key words: Enterobacteriaceae, chemosystematic, blood cultures, protein profile

\section{Introduction}

In Semarang, typhoid fever is determined as the third of 10 major diseases after Dengue Fever, diarrhea, and gastroenteritis (Anonymous, 2008). Typhoid fever is a systemic infectious disease caused by Salmonella typhi bacteria (S. typhi), with no specific clinical symptoms, thus the gold standard diagnosis of this disease should be

\section{*Corresponding author:}

Sri Darmawati

Microbiology Laboratory, Faculty of Nursing and Health, Universitas Muhammadiyah Semarang. Jl.Kedungmundu Raya No.18. Semarang.

Phone: 08122503552, E-mail: ciciekdarma@yahoo. com, conducted in laboratory tests (Koharo et al., 2010; Ley et al., 2010; Fadeel et al., 2011).

Widal test is considered as the simplest, easiest, cheapest and fastest laboratory test. However, its sensitivity, specificity and prediction value are varies because anti-O and anti-H can be found in patients infected by the member of Enterobacteriaceae familia species beside S. typhi (Novianti, 2006; Beig et al., 2010). The finding of $S$. typhi in blood cultures or in bone marrow is the gold standard of typhoid fever (Khoharo et al., 2010; Ley et al., 2010). Blood culture success rate varies from $40 \%$ to $89 \%$ compared to $S$. typhi isolation success rate. The success of obtaining $S$. typhi isolates from positive Widal blood cultures was $10.74 \%$ (Amarantini et al.2009). These showed that there are other bacteria types beside $S$. typhi 
such as Salmonella ssp., Escherichia coli (E. coli), Enterobacter cloacae (Ent. cloacae), Serratia marcescens (Ser. marcescens), and Klebsiella pneumoniae (Kleb. pneumoniae) (Darmawati et al., 2012).

Identification of species and strains diversity of bacteria can be conducted with polyphasic systematic approach, by combining the systematic of phenetics numeric, and molecular (Sembiring, 2004; Vandamme et al., 1996). This approach uses phenotypic and genotypic characteristics. The biochemical and chemical characteristics of total protein profile bacterial cell with sodium dodecyl sulphate polyacrylamide gel electrophoresis (SDS-PAGE) method can be used as chemical classification by numerical methods (Berber, 2004; Berber and Yenidunya, 2005; Amarantini, 2010; Yanti, 2011). The Diversity of bacterial species including Enterobacteriaceae familia and strain diversity of the member of each species can be classified based on the physiological characteristic differences, such as the ability of fermenting various carbohydrates, and its resistance to many antibiotics (Darmawati et al., 2011; Darmawati et al., 2012). This shows the existence of genetic variations in both inter-species and inter-individual member of each species.

Thus, the objective of was to classify bacteria of Enterobacteriaceae familia members based on its phenetics numeric in positive Widal blood cultures from Semarang based on its total protein profiles using UPGMA algorithm (unweighted pair group method with averages), so it enable to describe the similarities and differences of total protein profiles as genetic expression owned by each individual member of each species of bacteria, including Enterobacteriaceae that further can describe its morphology.

\section{Materials and Methods \\ Strains of bacteria}

There were 14 bacteria strains used in this study (4 strains of $S$. typhi: BA 07.4, 30.3 KD, KD 30.4, 02.2 SA; 1 strain of Salmonella ssp. BA 30.05, 2 strains of E. coli: BA and BA
30.130.2; 2 strains of Ser. marcescens: 08.4 KD, $08.5 \mathrm{KD}, 4$ strains of Ent. cloacae: BA 45.4.1, TG 03.5, KT 16, SA 02.1 and 1 strain of Kleb. pneumoniae KD 58.4) using one reference strain of $S$. typhi NCTC 786, from in and outpatient positive widal blood samples from Semarang (Tugurejo Hospital, Semarang Hospital, Sultan Agung Islamic Hospital, Bangetayu and Kedungmundu Public Health Centers). Bacterial identification was conducted by API 20E and API 50CHB /E media (Bio Merieux Inc.).

\section{The soluble total protein isolation and protein separation}

The soluble total protein was obtained by growing a colony of bacteria in $100 \mathrm{ml}$ of $\mathrm{BHI}$ liquid, incubated at $37^{\circ} \mathrm{C}$ for $18 \mathrm{~h}$. Bacteria cultures were then centrifuged at the temperature of $4^{\circ} \mathrm{C}$, at the speed of 3000 rpm for $20 \mathrm{~min}$. Presipitans were washed by suspending them using 0.1 M PBS (Phosphate buffered saline) at $\mathrm{pH} 7.4$. These washings were conducted 3 times. the presipitans then were re-suspended in $1.5 \mathrm{ml}$ PBS at pH7.4. The bacterial suspensions were sonicated 6 times in $30 \mathrm{sec}$ with the rest period of $30 \mathrm{sec}$ at $4^{\circ} \mathrm{C}$. repeating duty cycle Amplitude used was 0.7. The results of bacterial sonicated suspension were centrifuged at the temperature of 4 ${ }^{\circ} \mathrm{C}$, at the speed of $12000 \mathrm{rpm}$ for $20 \mathrm{~min}$. Supernatant obtained was the soluble total protein cells which protein concentration was readily measured using the reagent of Protein Assay CBB solution (5x) (Nacalai Tesque Inc.: code 29440-44, Kyoto Japan). The soluble protein absorption was then measured at a wavelength of $595 \mathrm{~nm}$ and separated using SDS-PAGE methods with ATTO corporation ATTA Tokyo Japan (AE-6530M/AE-6530P), stained with $0.25 \%$ Coomassie Brilliant Blue R250.

\section{Data analysis}

Data coding, unit character coding was done by giving a score. Positive unit character $(+)$ was given score 1 while the negative unit character (-) was given score 0 . The edited 
data was then analyzed using MVSP program (Multi-variate Statistical Package) version 3.1 A The inter-strains similarity relationship was known by using Simple Matching Coefficients $\left(S_{S M}\right)$. The clusterization is conducted by using unweighted Pair Group Methode with Averages (UPGMA) algorithms. The results of the analysis were finally presented in the form of dendrogram using Adhobe photoshop program.

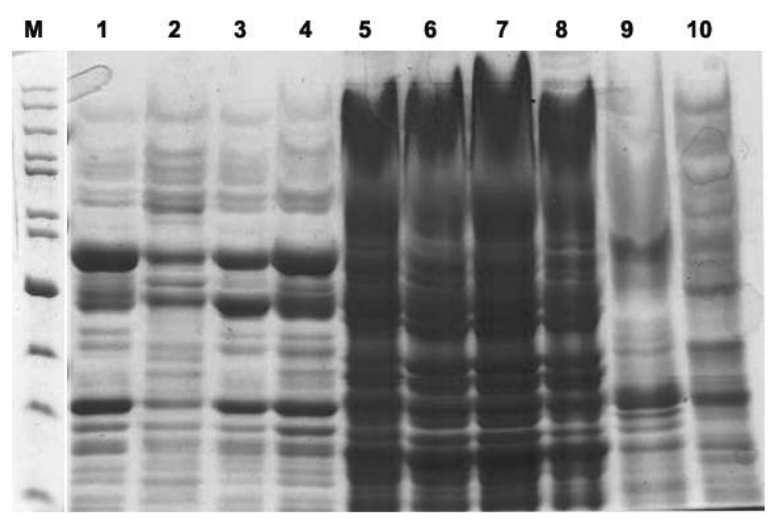

A

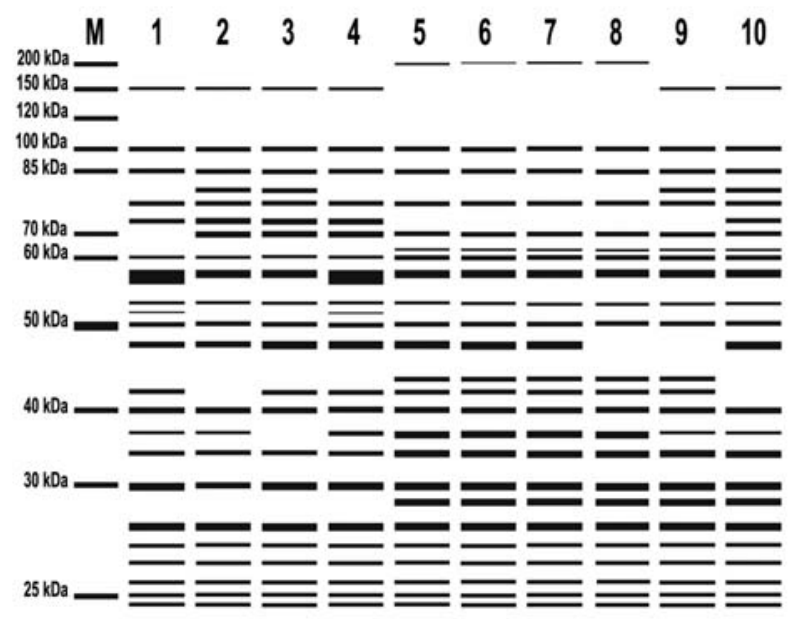

B

Figure 1.(A). Visualization of soluble total protein profiles onSDS-PAGE (B). Visualization of diagrammatic representation of 9 strain bacteria of Enterobacteriaceae familia members and the reference strains of $S$. typhi NCTC $786 \mathrm{M}$ of soluble total protein profiles) protein marker, 1) BA 07.4, 2) KD 30.3, 3) SA 02.2, 4) KD 30.4, 5) S. typhi NCTC 786, 6) BA 30.5, 7) BA 30.1, 8) BA 30.2, 9) KD 08.4, 10) KD 08.5

\section{Results and Discussion}

The separated soluble total protein bacterial cells by SDS-PAGE (Figure 1A and 2A), was visualized with diagrammatic representation (Figure 1B and 2B). Data was

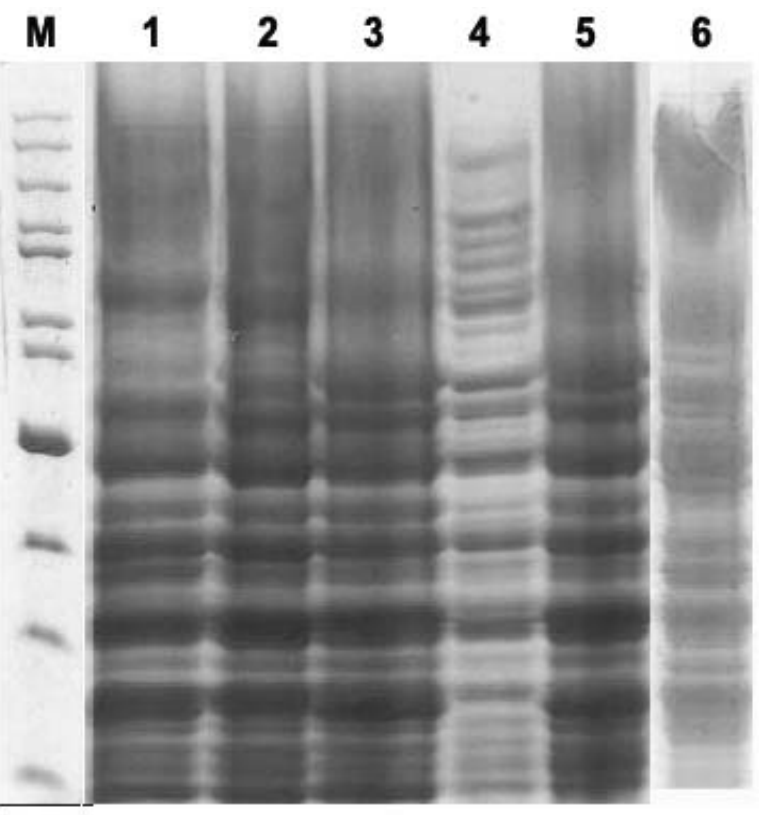

A

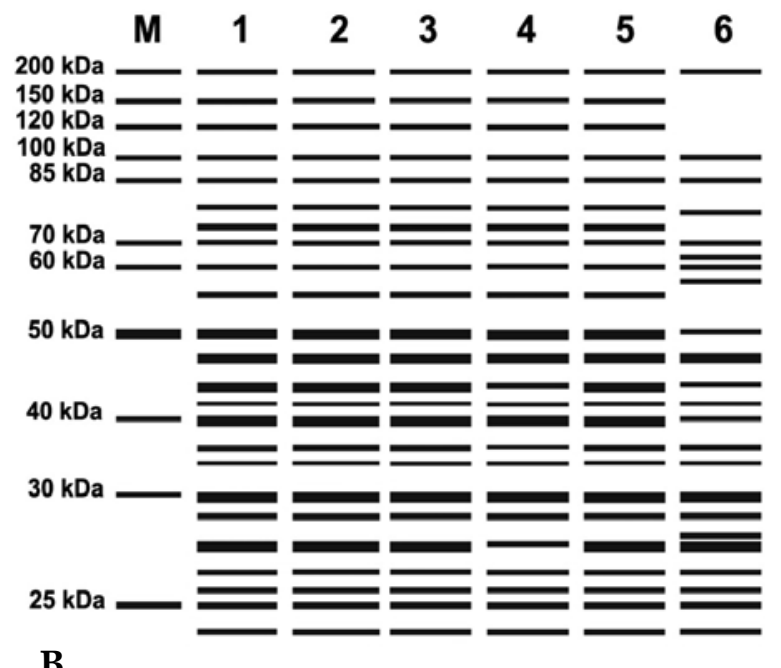

Figure 2. (A). Visualization of soluble total protein profiles onSDS-PAGE (B). Visualization of diagrammatic representation of five strains of Enterobacteriaceae familia members and the reference strain of $S$. typhi NCTC $786 \mathrm{M}$ of soluble total protein profiles) Marker protein, 1) BA 45.4.1, 2) TG 03.5, 3) KT 16, 4) SA 02.1, 5) KD 58.4, 6) S. typhi NCTC 786. 
then edited and analyzed with the MVSP 3.1A program, the inter-strains similarity relationship was analyzed with $S_{S M}$ and then was classified with UPGMA algorithm. The results of the analysis were presented in a dendrogram by Adhobe photo shop program (Figure 3 and 4).
The Dendrogram showing the similarity relationship between 9 strains of Enterobacteriaceae familia members and 1 reference strain S. typhi NCTC 786 (Figure 3) was composed into two clusters. The first cluster consists of four strains of $S$. typhi composed of 3 incorporated sub-clusters

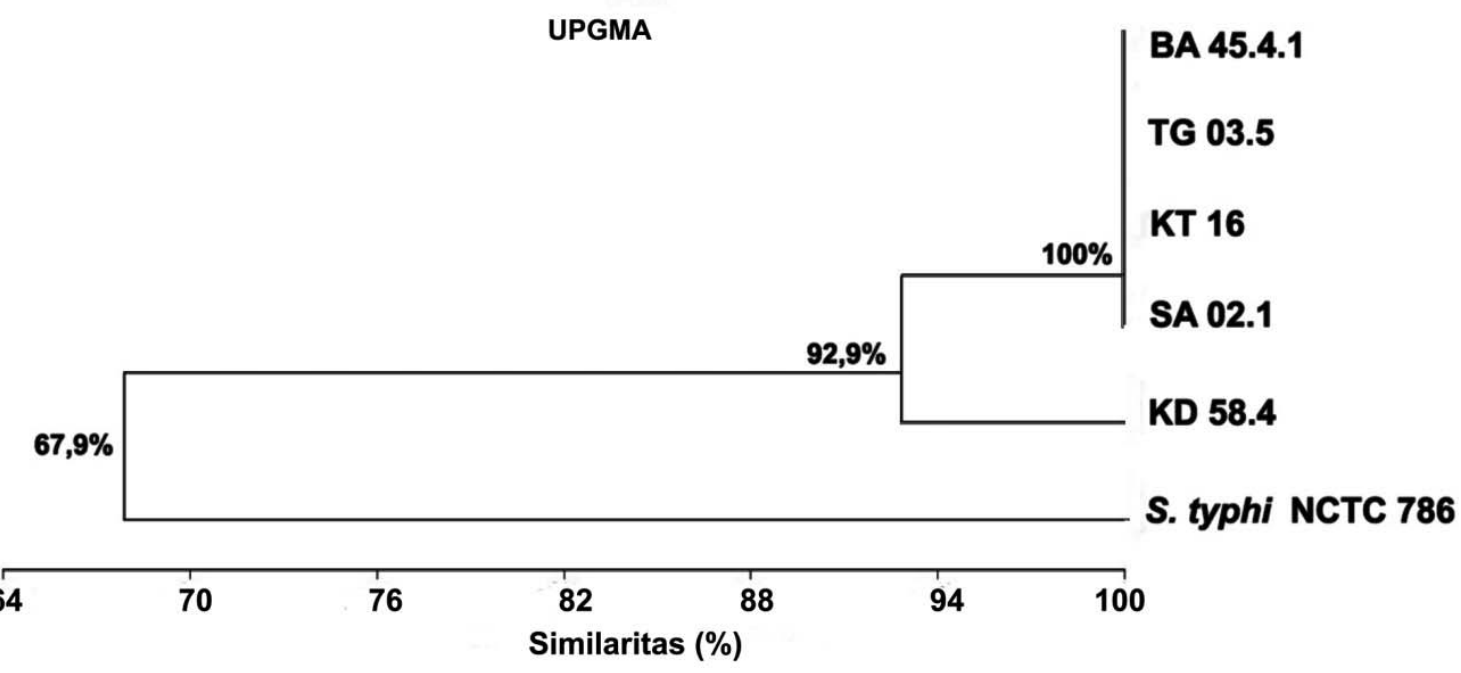

Figure 3. Dendrogram showing the similarity relationship between 9 strains of Enterobacteriaceae familia members (S. typhi SA 02.2; S. typhi KD 30.3; S. typhi BA 07.4; S. typhi KD 30.4; Ser. Marcescens KD 08.4; Ser. Marcescens KD 08.5; Salmonella ssp. BA 30.5; E. coli BA 30.2; E. coli BA 30.1) with reference strains of S. typhi NCTC 786 based on total protein profiles based on Simple Matching Coefficient analysis and UPGMA algorithm

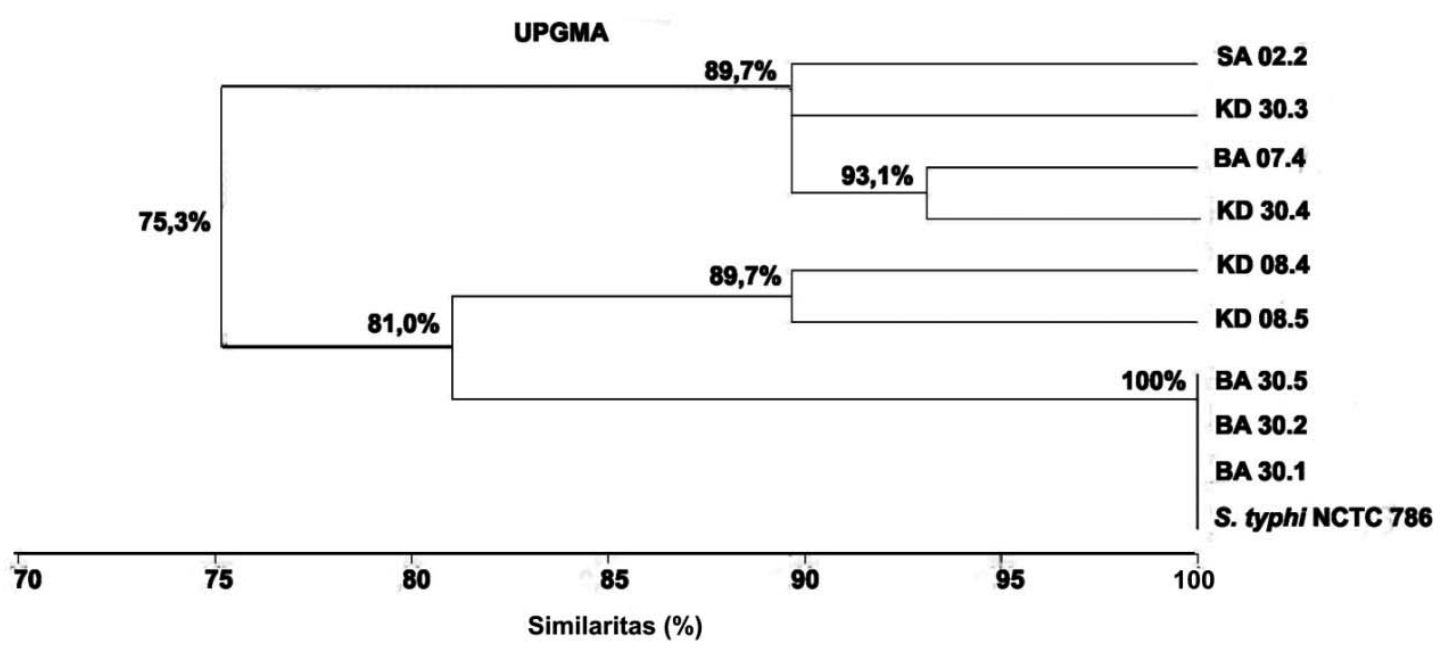

Figure 4. Dendogram showing the similarity relationship between the 5 strains of Enterobacteriaceae familia members (Ent. cloacae BA 45.4.1; Ent. Cloacae TG 03.5; Ent. Cloacae KT 16; Ent. Cloacae SA 02.1; Kleb. Pneumoniae KD 58.4)) with the reference strain of $S$. typhi NCTC 786 based on total protein profiles based on Simple Matching Coefficient analysis and UPGMA algorithm. 
with the similarity value of $89.7 \%$. The first sub-cluster consists of two strains (KD 30.3 and BA 07.4) with the similarity value of $93.1 \%$, the second and third sub-clusters each respectively consists of 1 strain; KD 30.3 and 02.2 SA. The second cluster was composed of two incorporated sub-clusters with the similarity value of $81.0 \%$. The first subcluster consists of two S.marcescens strains (KD 08.4 and KD 08.5) with the similarity value of $89.7 \%$, and the second sub-cluster was composed of four strains of bacteria consisting of two E. coli strains (BA 30.1 and BA 30.2), 1 Salmonella ssp. strain BA 30.5 and one reference strain of $S$. typhi NCTC 786 with incorporated similarity value of $100 \%$. The incorporated similarity value of the first and second clusters is $75.3 \%$.

The similarity relationship between 5 strains of Enterobacteriaceae familia members and 1 reference strain of $S$. typhi NCTC 786 is shown in the dendrogram (Figure 4) composed of two incorporated clusters with the similarity value of $67.9 \%$. The first cluster is composed of two sub-clusters; the first sub-cluster consists of 4 strains of Ent. cloacae (BA 45.4.1, TG 03.5, KT 16, SA 02.1) with the similarity value of $100 \%$, while the second sub-cluster consists of one strain of Kleb. pneumoniae KD 58.4.

Dendrogram (Figures 3 and 4) may indicate the diversity of bacteria species of Enterobacteriaceae familia members in clusters or sub-clusters levels. The strain members of S. typhi, Ser. marcescens, E. coli and Salmonella ssp. have higher similarity $(75.3 \%)$ upon the reference strain of $S$. typhi NCTC 786 than the strain members of Ent. cloacae and Kleb. pneumoniae upon the same reference strains $(67.9 \%)$. Both dendrogram composed based on the total protein profile has a similar topology with the dendrogram based on phenotypic characters characterized using API 20E and API 50CHB/E media (Darmawati et al., 2012). The results of this study are also in accordance with several other studies that the total protein profile analysis using SDS-PAGE method is identical to identification and classification results based on the biochemical characteristics (Amarantini, 2010; Yanti, 2011).

Vandamme et al. (1996) states that the total protein profiles obtained with SDSPAGE method can be used to compare and classify a number of strains. In addition, some studies have also shown that the total protein profiles have a high similarity with the results of DNA-DNA hybridization.

The results of classification based on biochemical characteristics seem congruent with the classification results based on the total protein profiles. These because biochemical characteristics are the enzymatic activity reflections that enzyme is composed of protein while protein is genome reflection, thus the classification based on biochemical characteristics and total protein profiles will result an accurate classification.

\section{Acknowledgments}

The author would like to thank the Directorate General of Higher Education, Ministry of National Education, Republic of Indonesia through Kopertis VI Jawa Tengah for funding the 2013 Competitive Grant Study.

\section{References}

Amarantini, C., W. Asmara, W., Kushadiwijaya, H., and Sembiring, L. , 2009. Selection Salmonella typhi bacteria of blood culture Patients with Typhoid Fever. Proceedings of the National Seminar on Research, Education and Application of Mathematics and Science. Faculty of Science. State University of Yogyakarta. ISBN: 978-979-96880

Amarantini, C., 2010. The Molecular Epidemiology of Salmonella typhi. The Cause of Typhoid Fever in the Endemic region of the Southest Sumba District, East Nusa Tenggara. Dissertation. Biotechnology. Universitas Gadjah Mada. Yogyakarta

Anonymous, 2008. Profil Kesehatan Kota Semarang 2008. Dinas Kesehatan Kota Semarang, Jawa Tengah, Indonesia 
Beig, F. K., Ahmad, F., Ekram, M., Shukla, I. 2010. Typhidot M and Diazo test vis-à-vis blood culture and Widal test in the early diagnosis of typhoid fever in children in a resource poor setting. Braz. J. Infect. Dis. 14 (6), 589-593.

Berber, I. 2004. Characterization of Bacillus species by numerical analysis of their SDS-PAGE protein profiles. J.Cell Mol. Biol. 3, 33-37.

Berber, U. and Yenidunya, E. 2005. Identification of Alkaliphilic Bacillus Species Isolated from Lake Van and Its Surroundings by Computerized Analysis of Extracellular Protein Profiles. Turki J. Biol. 29,181-188.

Darmawati, S. Sembiring, L., Asmara, W., and Artama, W.T. 2011. Numerical Classification-fenetik Sal Salmonella typhi from Central Java and Yogyakarta Based on Phenotypic Characterization results. Biota. 16 (1) I

Darmawati, S. Sembiring, L., Asmara, W., Artama, W.T. 2012. Bacteria Species Diversity of Positive Widal Blood cultures from Semarang Based Phenotypic characters. Proceedings of the National Seminar on Biology of Sebelas Maret University of Surakarta. ISBN: 978-6028580-51-9

Fadeel, M. A., House, B. L., Wasfy, M. M., Klena,J.D., Habashy, E.E., Said, M.M.,Maksoud, M.A.,Rahman, B.A and Pimentel, G. 2011. Evaluation of a newly developed ELISA against Widal, TUBEXTF and Typhidot for typhoid fever surveillance. J. Infect. Develop. Countr. 5(3), 169-175

Khoharo, H. K., Ansari, S and Qureshi, F. 2010. Evaluating Single Acute-phase Widal test for the diagnosis of Typhoid Fever. Medical Channel. 16 (1), 42-44

Ley, B., Mtove, G., Thriemer, K., Amos,B., Seidlein,L., Hendriksen, I., Mwambuli,A., Shoo,A., R. Malahiyo, R.,Ame, S. M.,Kim, D.R., Ochial, L.R.,Clemens, J.D.,Reyburn, H., Wilfing,H., Magesa, S., and Deen, J.L. 2010. Evaluation of the Widal tube agglutination test for the diagnosis of typhoid fever among children admitted to a rural hospital in Tanzania and a comparison with previous studies. BioMed Central Infect. Dis. 10, 180

Novianti, T. , 2006. Examination of AntiSalmonella typhi IgM for Typhoid Fever Diagnosis Laboratory Information. ISSN 0854-7165. No. 5/2006.

Sembiring, L. , 2004. The Roles of Biosystematics In Supporting biological diversity Utilization National Seminar on Biology. 25 September 2004. Sepuluh November Institute of Technology of Surabaya

Vandamme, P., Gills, B.P.M., De Vos, P., Kerstres, K., and Swings, T. 1996. Polyphasic Taxonomy, A Consensus Approach to Bacterial Systematic. Microbiol.Rev., 60 (2), 407-438

Yanti, N.A. 2011. Study of Poly$\beta$-Hydroxybutyrate (PHB) Producing Amylolytic Bacteria from Sago Starch. Disertasion Biology Faculty. Universitas Gadjah Mada. Yogyakarta 